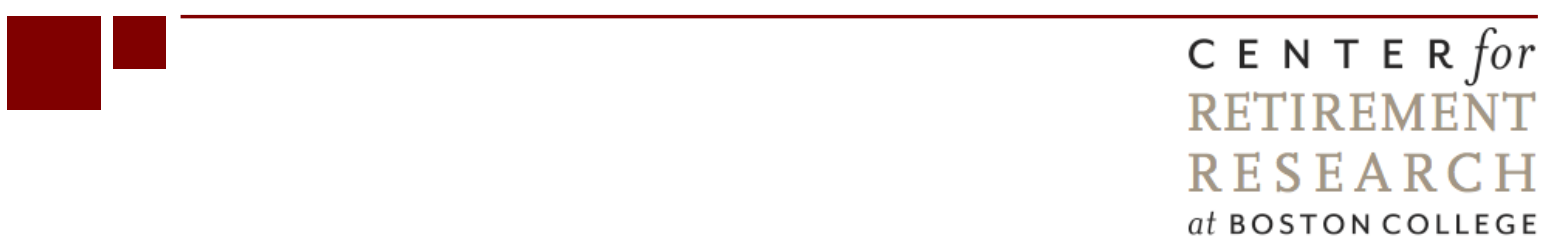

\title{
SOCIAL SECURITY CLAIMING: TRENDS AND BUSINESS CYCLE EFFECTS
}

Owen Haaga and Richard W. Johnson

CRR WP 2012-5

Date Released: February 2012

Date Submitted: January 2012

Center for Retirement Research at Boston College

Hovey House

140 Commonwealth Avenue

Chestnut Hill, MA 02467

Tel: 617-552-1762 Fax: 617-552-0191

http://crr.bc.edu

Owen Haaga is a research associate at the Urban Institute. Richard W. Johnson is a senior fellow and director of the Program on Retirement Policy at the Urban Institute. The research reported here was performed pursuant to a grant from the U.S. Social Security Administration (SSA) funded as part of the Retirement Research Consortium (RRC). The opinions and conclusion expressed are solely those of the authors and do not represent the opinions or policy of SSA, any agency of the federal government, the RRC, the Urban Institute, or Boston College.

(C) 2012, Owen Haaga and Richard W. Johnson. All rights reserved. Short sections of text, not to exceed two paragraphs, may be quoted without explicit permission provided that full credit, including (C) notice, is given to the source. 


\begin{abstract}
About the Center for Retirement Research
The Center for Retirement Research at Boston College, part of a consortium that includes parallel centers at the University of Michigan and the National Bureau of Economic Research, was established in 1998 through a grant from the Social Security Administration. The Center's mission is to produce first-class research and forge a strong link between the academic community and decision-makers in the public and private sectors around an issue of critical importance to the nation's future. To achieve this mission, the Center sponsors a wide variety of research projects, transmits new findings to a broad audience, trains new scholars, and broadens access to valuable data sources.
\end{abstract}

Center for Retirement Research at Boston College

Hovey House

140 Commonwealth Avenue

Chestnut Hill, MA 02467

phone: 617-552-1762 fax: 617-552-0191

e-mail: crr@bc.edu

crr.bc.edu

Affiliated Institutions:

The Brookings Institution

Massachusetts Institute of Technology

Syracuse University

Urban Institute 


\begin{abstract}
This study examines Social Security claiming behavior, which has important implications for older Americans and for the system itself. Retirees may begin collecting benefits as early as age 62, but early claimants receive lower monthly benefits for the rest of their lives. Our data come from Survey of Income and Program Participation (SIPP) files from 1984 to 2009 linked to administrative records on earnings and benefits. The sample is restricted to respondents with 40 quarters of covered employment who did not claim benefits before age 62. Results indicate that early claiming has declined over the past decade, after increasing over the previous 10 years. For men, the share claiming at age 62 fell from 55.3 percent in the 1930-34 birth cohort to 46.4 percent in the 1940-44 cohort. Over the same period, the share of women claiming at 62 fell from 59.3 to 49.0 percent. The recent trend toward delayed claiming is evident among all educational groups, not just college graduates. Hazard models show that high unemployment boosts Social Security claiming among men with limited education. A 1 percentage point increase in the state unemployment rate is associated with a 0.4 percentage point increase in the likelihood each month that men who never attended college will claim benefits, a relative increase of 6 percent. This estimate implies that the Great Recession increased claiming for men with limited education by about 40 percent. Claiming behavior among women and welleducated men is not significantly correlated with the state unemployment rate, however.
\end{abstract}




\section{Policy Abstract}

This study uses household survey data from 1984 to 2009 linked to administrative earnings and benefits records to examine Social Security claiming behavior, which has important implications for older Americans and the system itself. Retirees may begin collecting benefits as early as age 62 , but early claimants receive lower monthly benefits for the rest of their lives. Results indicate that early claiming declined over the past decade, after increasing over the previous 10 years. For men, the share claiming at age 62 fell from 55.3 percent in the 1930-34 birth cohort to 46.4 percent in the 1940-44 cohort. Over the same period, the share of women claiming at 62 fell from 59.3 to 49.0 percent. The recent trend toward delayed claiming is evident among all educational groups, not just college graduates. Findings from our models show that high unemployment boosts Social Security claiming among men with limited education. A 1 percentage point increase in the state unemployment rate is associated with a 0.4 percentage point increase in the likelihood each month that men who never attended college claim benefits, a relative increase of 6 percent. This estimate implies that the Great Recession increased claiming for men with limited education by about 40 percent. Claiming behavior among women and well-educated men is not significantly correlated with the state unemployment rate, however. Unemployment's large effect on claiming for less-educated men is consistent with their disproportionately high rates of job loss during economic downturns. 


\section{Introduction}

The timing of Social Security claims has important implications for older Americans and the system itself. Retirees may begin collecting benefits as early as age 62 , but early claimants receive lower monthly benefits for the rest of their lives. This offset is designed to be actuarially fair overall, but groups with lower-than-average life expectancy gain by claiming early (and the system loses), whereas groups with higher-than-average life expectancy lose by claiming early. Surviving spouses may receive higher Social Security survivor benefits when their deceased husbands or wives wait until after the full retirement age (FRA) to claim Social Security. Moreover, most older adults can benefit financially by delaying claiming and continuing to work because their earnings during those months will generally exceed what they would have received in retirement benefits, they can save part of their additional earnings for retirement, and they will receive higher monthly Social Security benefits when they eventually retire. Those additional earnings also generate income and payroll tax revenues, helping to finance Social Security and other government services.

Social Security claiming is usually tied to work decisions, since the retirement earnings test (RET) prevents workers who earn more than a certain amount from receiving much Social Security before the FRA, and many people cannot afford to stop working until they collect Social Security. Changing Social Security and other government policies, employer practices, and population characteristics appear to be shifting work decisions and claiming behavior. The business cycle likely also affects claiming decisions. Job layoffs may lead some workers who cannot find employment to claim Social Security earlier than they planned, reducing their future retirement incomes. 
High unemployment rates may especially promote early claiming among workers with limited education, who are most likely to lose their jobs during economic downturns.

This study uses household survey data from 1984 to 2009 linked to administrative records on earnings and benefits to examine Social Security claiming behavior. An updated study of claiming behavior seems warranted in light of ongoing changes to the retirement landscape and the high unemployment that persists in the aftermath of the Great Recession. This report examines the characteristics of early claimants and how they have changed over time. It then explores the determinants of Social Security claiming and shows how it responds to the business cycle. Results indicate that early claiming has become less common over the past 10 years for all educational groups — not just welleducated adults — and that high unemployment promotes early claiming among men with limited education.

\section{Background}

Monthly retirement benefits paid by Social Security generally depend on the worker's lifetime earnings and the timing of benefit take-up. Workers qualify for benefits once they have accumulated 40 quarters of covered employment. They are credited with a quarter of coverage once they earn a certain amount in a given year (set at \$1,130 in 2012), and may earn up to four quarters per year. Social Security indexes and averages monthly earnings received in the worker's top 35 earning years (up to the taxable maximum each year) and converts them into a primary insurance amount (PIA) using a progressive formula that favors those with low lifetime earnings. 
Monthly payments are set equal to the PIA for adults who begin collecting retired worker benefits at the FRA. Retirees may instead begin collecting benefits as early as 62 , the current early entitlement age, or they can wait until after the FRA to collect. Monthly benefits are actuarially adjusted so that expected lifetime payments are about the same no matter when beneficiaries choose to collect. Those who retire early receive lower monthly benefits than those who collect at the FRA, and those who retire later receive higher benefits. However, the delayed retirement credit (DRC) boosts monthly benefits for those who delay take-up only up to age 70 . There is no financial gain from delaying take up beyond age 70 .

Some people also collect on their current, former, or deceased spouse's earnings records. Spouse benefits equal 50 percent of the worker's PIA if the spouse collects at his or her FRA, and survivor benefits are set equal to 100 percent of the worker's PIA. Spouses may not claim benefits before the worker claims. As with individuals collecting worker benefits, those collecting spouse and survivor benefits face actuarial reductions if they collect before the FRA. Workers who delay claiming beyond the FRA and thus receive monthly benefits that exceed their PIA are able to pass those higher benefits onto their surviving spouses. Unlike workers and spouses, who cannot collect until age 62, widows and widowers may begin collecting at age 60 . Workers with serious health problems sometimes qualify for Social Security disability insurance (DI) benefits, which may begin before the early entitlement age and are not subject to actuarial reductions.

The take-up age is important because it substantially affects retirement benefits. An adult born in 1947 (who turned age 62 in 2009) increases her monthly Social Security retired worker benefits by a third by waiting until age 66 (her FRA) to collect instead of 
collecting at 62 . She can collect 76 percent more each month by claiming benefits at age 70 instead of 62 . Although the reduction for early claiming and bonus for delayed claiming are designed to be actuarially neutral overall, many people can gain substantially by delaying, including those with longer life expectancies (because they will receive higher benefits longer than average), married adults (because their spouses can inherit their higher benefits), and those who discount the future less than others (Coile et al. 2002).

Social Security claiming is often tied to work decisions. Social Security's RET reduces payments for working beneficiaries younger than the FRA who earn above a specified threshold, so relatively few full-time workers in their early sixties are able to collect Social Security. Moreover, relatively few older adults can afford to stop working before they begin collecting Social Security. Only about 10 percent of men who stopped working in the late 1970s and early 1980s before age 62 delayed claiming Social Security (Coile et al. 2002). Thus, although employment and claiming are two distinct decisions, the factors that affect labor supply tend to affect claiming as well.

\section{Changes in Social Security}

Changes in the retirement landscape are leading both men and women to work longer. Between 1990 and 2010, labor force participation rates at ages 62 and older increased from 22 to 29 percent for men and from 12 to 20 percent for women (Urban Institute Program on Retirement Policy 2011a, 2011b). Blau and Goodstein (2010) estimate that increases in Social Security's FRA and DRC explain between one-fourth and one-half of the recent growth in older men's labor force participation. The FRA had been 65 since 
Social Security was created, but the 1983 Social Security amendments gradually began increasing it for those born in 1938 and later, who began turning 62 in 2000. The FRA increased two months each year, until it reached 66 for those born in 1943 (who turned 62 in 2005). The FRA remains at this level for the next several years. It begins increasing two months per year again for those born in 1955 (and turning 62 in 2017), until it reaches 67 for those born in 1960 and later. Retirees may still claim Social Security at age 62, the early entitlement age, but those who face a higher FRA are penalized more for early claiming. When the FRA is 66 , those who claim at age 62 receive only 75 percent of their full benefits, whereas those facing an FRA of 65 receive 80 percent of their full benefits when they begin collecting at age 62 . When the FRA is 67 , age-62 claimants receive only 70 percent of their full benefits.

Additionally, the DRC has increased sharply over time, further encouraging later claiming. When first implemented in 1972, it increased benefits by 1 percent for each year that the beneficiary waited beyond the FRA to collect, up to age 72 . The credit increased to 3 percent per year in 1981. The 1983 amendments included additional increases that began with those born in 1925 , whose credit was boosted to 3.5 percent per year, but stopped increasing benefits for who waited beyond age 70 to claim. They further increased the credit by 0.5 percentage points every other year until it reached 8 percent per year for those born in 1943 and later.

Changes in the RET also appear to have changed work and claiming decisions. The RET originally applied to all Social Security beneficiaries, regardless of age. For beneficiaries below the FRA, Social Security withheld $\$ 1$ in benefits for every $\$ 2$ of earnings in excess of a specified exempt amount. For beneficiaries at or above the FRA, 
Social Security withheld $\$ 1$ in benefits for every $\$ 3$ of earnings in excess of a different higher exempt amount. Beginning in 1981, the earnings test did not apply to working beneficiaries age 70 or older. The Senior Citizens' Freedom to Work Act of 2000 eliminated the retirement earnings test above the FRA. For working beneficiaries below the FRA, the retirement earnings test currently reduces benefits by $\$ 1$ for every $\$ 2$ of earnings in excess of the exempt amount-\$14,640 in 2012. For working beneficiaries at the FRA, it reduces benefits by $\$ 1$ for every $\$ 3$ of earnings in excess of a higher exempt amount $-\$ 38,880$ in 2012 . The benefit reduction while working is partly offset by higher future benefits, but many beneficiaries may not realize that their benefits will increase in later years. In fact, several studies have found that workers responded to the elimination of the retirement earnings test by working more (Friedberg 2000; Haider and Loughran 2008; Song 2004; Tran 2004) or taking Social Security benefits earlier (Gruber and Orszag 2003; Song and Manchester 2007).

\section{Changes in Employer Practices}

The most dramatic change in the retirement environment over the past few decades has probably been the growth in employer-sponsored defined contribution (DC) retirement plans and the erosion in traditional defined benefit (DB) pension plan coverage. Thirtynine percent of private sector workers were covered by DB plans in 1980, compared with 19 percent in 2010 (Bureau of Labor Statistics 2010; Pension and Welfare Benefits Administration 2001-2002). During the same period, the share participating in DC plans increased from 19 to 41 percent. 
This shift significantly affects retirement incentives. Once DB plan participants have satisfied the plan's service requirements and reach retirement age, they may leave their employer and begin collecting monthly retirement benefits, which are generally based on earnings and years of service and last until they die. Participants may generally raise their monthly retirement benefits by working beyond the plan's retirement age, as years of service (and sometimes annual earnings) increase. However, the increase in monthly benefits resulting from an additional month of work is usually insufficient to fully offset the loss of a month of benefits. As a result, most traditional DB plans penalize work beyond the plan's retirement age. Numerous studies have found that workers respond to the incentives embedded in DB pension plans by retiring at relatively young age (e.g., Lumsdaine, Stock, and Wise 1996; Samwick 1998; Stock and Wise 1990). DC retirement plans, by contrast, do not encourage workers to retire early. Most DC plans function essentially as tax-advantaged savings accounts to which both employers and employees contribute. Workers gain access to their accumulated account balance when they retire. Because the account balance may continue to grow while participants remain in the plan and workers do not forfeit any benefits by remaining with the employer beyond traditional retirement ages, DC plans do not penalize work at older ages. In fact, Friedberg and Webb (2005) found that older workers in DC plans generally retire about two years later than those in DB plans.

Many employers are cutting back on retiree health benefits, inducing many workers to postpone retirement. Retiree health benefits generally allow workers to continue their employer health insurance coverage after they retire until they qualify for Medicare benefits at age 65 . Some retiree health plans also supplement Medicare benefits 
after age 65 . By lowering retirement costs, these benefits reduce work incentives and encourage early labor force withdrawals (Blau and Gilleskie 2001; Johnson, Davidoff, and Perese 2003; Rogowski and Karoly 2000). However, the share of employers offering retiree health benefits has declined dramatically over the past two decades as health care costs have increased. Among large private-sector employers (with 200 or more employers) that provided health benefits, only 29 percent offered retiree health benefits in 2009, down from 66 percent in 1988 (Kaiser Family Foundation and Health Research and Educational Trust 2009). Additionally, the retiree health benefits that employers provide have generally become less generous over time and now shift more costs to retirees (Johnson 2007; Laschober 2004). This erosion in retiree health benefits discourages early retirement. ${ }^{1}$

\section{Changes in Worker Characteristics}

Older adults are generally healthier and better educated today than in previous generations, increasing their employability and willingness to work. For example, the share of Americans age 65 to 74 reporting fair or poor health fell from 32.5 in 1983 to 21.6 percent in 2008 (National Center for Health Statistics 2011). A generation ago firms may have preferred younger workers because they were generally better educated than older workers. In 1980, men age 62 to 64 were only half as likely as men age 35 to 49 to hold a four-year college degree (Johnson forthcoming). Today, however, older men are better educated than their younger counterparts, boosting their employment prospects.

\footnotetext{
1 The 2010 Affordable Care Act establishes health insurance exchanges in 2014 that may substantially reduce the cost of nongroup health insurance coverage and thus the importance of retiree health benefits in coming years.
} 
Older women's educational disadvantage relative to younger women has not disappeared, but it has narrowed considerably. These health and education trends have both raised labor force participation at older ages (Blau and Goodstein 2010; Mermin, Johnson, and Murphy 2007).

Women's increased employment also appears to have led many married men to postpone retirement. Because husbands and wives often prefer to spend their leisure time together and husbands tend to be a few years older than their wives, men are increasingly working longer and waiting to retire until their wives leave the labor force. One study finds that women's employment gains explains about a fourth of the recent increase in older men's labor force participation (Schirle 2008).

\section{Claiming and the Business Cycle}

The business cycle likely affects claiming decisions. Older adults are less likely to work when labor demand is weak and unemployment is high. For example, older men's labor force participation generally falls as the state unemployment rate rises (Munnell et al. 2008). Local unemployment, measured at the metropolitan area level, reduces voluntary retirements among older workers and increases involuntary retirements (Friedberg, Owyang, and Webb 2008). The effects are especially large for men and semi-skilled workers, who are more likely than others to lose their jobs during economic downturns (Johnson and Mommaerts 2011). Social Security provides an important safety net for older displaced workers. Household incomes fall less after a job layoff for workers age 62 or older than younger workers, because most older displaced workers begin collecting Social Security (Butrica and Johnson forthcoming). Many of these older displaced 
workers received unemployment insurance benefits as well, because few states now restrict unemployment benefits for Social Security beneficiaries. Hutchens (1999) argues that the availability of early Social Security benefits makes it easier for employers to lay off older workers.

Figure 1 shows the number of Social Security benefit awards and DI applications between 1978 and 2010. Shaded areas in the figure identify recessionary years, as defined by the National Bureau of Economic Research. The graph reveals rapid growth in retired worker awards since 2007, the year just before the oldest baby boomers - the unusually large cohort born between 1946 and 1964 - turned 62 and qualified for retirement benefits. Auxiliary awards (primarily to spouses and survivors) increased only modestly since 2007, primarily because as women's lifetimes earnings have risen more are claiming on their own earnings records and fewer on their current or former husband's records. DI applications and awards have increased as the population has aged (Autur and Duggan 2003). The figure reveals a surge in retired worker awards (and DI applications) in 2009 as unemployment soared during the Great Recession, suggesting that claiming responds to poor economic conditions. This relationship is less evident in other recessions, however. A model that controls for other factors that affect claiming is necessary to establish a clear relationship between Social Security claiming and the business cycle.

\section{Existing Claiming Literature}

Several existing studies examine Social Security claiming behavior and the characteristics of those who claim early. Li, Hurd, and Loughran (2008) find that those 
who claim at age 62 are about twice as likely to report a health-related work limitation as those who postpone claiming until after age 62 . Early claimants are also more likely to have worked in physically demanding jobs. Nonetheless, most of those who collected at age 62 in the early 1990s were in good health, and more than three-fifths received employer-sponsored pensions (Burkhauser, Couch, and Phillips 1996). Later claimants tend to live longer than those who claim at age 62. Coile et al. (2002) find that living to age 70 reduces the hazard rate of claiming by 15 percent, and Hurd, Smith, and Zissimopoulos (2002) find that retired workers who report that they expect to survive into old age are less likely to claim than those with moderate or low survival probabilities.

Given rapid changes in the retirement environment, an updated study of Social Security claiming seems warranted. Song and Manchester (2007) show that claiming patterns have shifted in the 2000 s, as Social Security rules have changed. Some of the existing studies use data that are now quite old. Coile et al. (2008), for example, is based on a sample of Social Security beneficiaries who claimed in 1980 and 1981. Moreover, none of the existing studies on Social Security retirement claiming specifically examines the effect of the business cycle, an important issue in times of high unemployment.

\section{Methods}

Our data come from the Survey of Income and Program Participation (SIPP) matched to administrative records that allow us to measure lifetime earnings and the timing of Social Security benefit claiming. The SIPP is a nationally representative longitudinal household survey conducted by the U.S. Census Bureau that collects data on employment, job characteristics, income, assets, program participation, health status, demographics, and 
other topics. It consists of a series of panels that follow respondents from between twoand-a-half and four years. Households are surveyed every four months, but SIPP collects information from respondents on many topics, including employment and income, for each of the preceding three months as well as the survey month. We use the following SIPP panels: 1984 (which first interviewed respondents in September 1983, collecting data from as early as June 1983), 1990, 1991, 1992, 1993, 1996, 2001, 2004, and 2008. The most recent available interview from the 2008 panel was conducted in July 2010. Each of the SIPP panels we examine has been linked to Summary Earnings Records (SER) and the Master Beneficiary Record (MBR). These special linked files may be accessed by researchers who have been granted special permission and who follow strict protocols in secure data facilities. The SER reports earnings in Social Security-covered employment each year up to the earnings cap. The MBR indicates the date of initial Social Security benefit receipt, the amount received each month, and the type of benefit received (i.e., retirement, disability, or survivor). These records begin in 1951 and are now available through 2009.

There are several important advantages of using SIPP interview data linked to administrative records to study how the business cycle affects Social Security claiming behavior. The share of SIPP respondents with valid matches varies from panel to panel (Sears and Rupp 2003), but the overall match rate is quite high, averaging 83 percent for the 1996, 2001, 2004, and 2008 panels (Favreault and Nichols 2011). By comparison, the match rate is much lower in the Health and Retirement Study, the nation's premier aging dataset which also includes links to Social Security administrative data but only for respondents who explicitly grant permission for such linkages. Moreover, SIPP 
respondents with valid links to administrative records do not appear to differ systematically from those without valid links (Czajka, Mabli, and Cody 2008), so analyses restricted to linked respondents are unlikely to be badly biased. The multiple SIPP panels and linked administrative data span several decades, running from 1983 to 2009, allowing us to observe several recessions (those of 1990-91, 2001, and 2007-09, when unemployment was especially high, as well as the aftermath of the 1981-82 recession). Our sample also covers periods of strong economic growth and low unemployment. Although our sample is quite large, it is much smaller than the millions of records available in unlinked administrative files. However, we have access to survey information (such as health status, education, and wealth) that are not available in administrative files and that likely have strong effects on claiming behavior. We also have information on eligible adults who have not yet claimed. Additionally, the survey includes indicators for state of residence, allowing us to link respondents to state unemployment rates.

\section{Descriptive Analyses}

We begin by showing how Social Security claiming ages have changed over time and how they vary by education, earnings, and health status. For these analyses we pool all of our linked SIPP panels and compute Social Security claiming ages for those with at least 40 quarters of covered earnings who survive to age 62 . Only adults with 40 or more quarters of earnings are eligible to claim on their own records. (People may also claim on their spouses' earnings records, but only if the spouse has already claimed or is deceased.) We calculate claiming ages by education and lifetime earnings quartile as of 
age 61 . Earnings are adjusted by changes in the consumer price index and quartiles are computed separately by sex and five-year birth cohort (except when otherwise noted). All of our tabulations are conducted separately for men and women, because claiming ageslike employment - vary by sex. For each of these groups, we report the share who claim at age 62,63 or 64 , and age 65 and older, for those who did not claim before age 62 . Some tabulations also show the share who claim at age 66 and after age 66 .

Our analyzes exclude those who claim before 62 because few adults are eligible to claim that early. Generally only adults with severe disabilities and widows and widowers may claim benefits before age 62. Figure 2 shows how the share of men and women claiming Social Security before age 62 has changed over time. (This sample is restricted to men and women who have accumulated at least 40 quarters of covered earnings or claimed before age 62, and consists of 45,771 men and 44,012 women.) The increase in pre-62 claiming by men is striking, growing from 9 percent of those born in 1920 to 15 percent of those born in 1947, a relative increase of two-thirds. This trend is consistent with the well-documented secular increase in disability claimants (Autur and Duggan 2003). For women, we see a decline in the share claiming before age 62 between those born in 1920 and those born in 1932 (likely reflecting a drop in early claiming by widows), followed by an increase among those born over the subsequent 15 years (likely reflecting heightened disability claiming). Although women remain more likely than men to claim before age 62 , the gap is much smaller among those born in the 1930 and 1940 s than among those born in the 1920s.

Because our first set of tabulations incorporates only data from administrative records (date of initial benefit receipt, lifetime earnings, number of covered quarters) or 
time-invariant data from the SIPP interviews (education, sex), we do not need to restrict the sample to respondents who were interviewed at the time they claimed. Including those interviewed by SIPP long before they claimed or long afterwards enables us to greatly increase our sample size. However, we need to consider carefully sample selection issues, especially with regard to mortality. Everyone in our linked dataset must have survived to the SIPP interview. Thus, if we include those born in 1910, say, we are implicitly conditioning on surviving to age 73 (their age in 1983 when the first panel [1984] begins). Those who survive to age 73 may exhibit different claiming behavior than those who survive only to 62 , so this condition could bias our estimates. To reduce the potential for this type of mortality bias, we generally restrict our sample to those born after 1919. The earliest cohort in our sample — those born in 1920 — need only survive to age 63 for inclusion in the analyses. We also restrict this sample to respondents born in 1944 or earlier. Those in the most recent birth cohort are age 65 in 2009, the most recent year that we have linked administrative records. This sample includes 40,225 men and 37,630 women.

We then dig deeper into early claiming behavior by showing how the share claiming within the first three months of turning 62 - their first year of eligibility for retirement benefits in most cases_changes over time. These tabulations show claiming for men and women who turn 62 between 1978 and 2009.

Our final descriptive analysis shows how claiming behavior varies by health status. SIPP respondents are asked periodically (in topical modules) to rate their health status as excellent, very good, good, fair, or poor. Because this information is available only during the observed SIPP panel, for this analysis we restrict our sample to 
respondents born between 1930 and 1944, all of whom are interviewed at age 62 .

However, health status is not collected at the same age for all respondents. We measure health status at the age when the information is collected that is closest to 62 . This sample includes 9,507 adults. Because the sample is relatively small, we show differences in claiming by health status only for men and women combined.

\section{Estimating hazard models}

We then estimate probit models of the probability of claiming Social Security benefits at age 62 or later. Because the data are arranged in person-month format, the sample is restricted to those eligible for benefits (40 or more covered quarters), and respondents are dropped from the sample once they have taken up benefits (and thus are no longer at risk of claiming), the results can be interpreted as discrete-time hazard models of benefit claiming (Allison 1984). The advantage of these models is that they readily accommodate time-varying predictors. We estimate separate models for men and women. The dependent variable equals one if the respondent claims in the next month, zero otherwise. The model includes controls for the state-level unemployment rate, the natural log of lifetime earnings, the increase in monthly benefits that would result from delaying takeup one month, health status, year of birth, and demographics (education, marital status, race, and age). Because monthly benefits spike upward from zero when people first qualify, we set the variable measuring the change in monthly benefits associated with delayed claiming equal to zero for the first month of eligibility and include in the model a dummy variable identifying the first eligibility month. This approach prevents the benefit change variable from merely reflecting adults claiming at the first opportunity, which is common (Coile et al. 2002). The lifetime earnings measure sums earnings in Social 
Security covered employment through age 61 , adjusted each year by the change in average annual earnings. The sample includes 37,912 person-month observations on 4,199 men and 33,881 person-month observations for 3,900 women.

\section{Results}

This section shows how the distribution of claiming age has changed over time for men for women, and how it varies by education, lifetime earnings, and health status. Results are then reported for our hazards models of retirement benefit claiming.

\section{Claiming Ages by Cohort}

Figures 3 and 4 show the overall age pattern of claiming behavior for men and women age 62 and older with 40 quarters or more of covered earnings. For men, the share claiming at 62 increases from 49.5 to 55.3 percent between the 1920-24 and 1930-34 cohorts, but then declines steadily, falling to 46.4 percent for the $1940-44$ cohort (figure 3). The share claiming at ages 63 or 64 declines from 27.2 percent in the 1920-24 cohort to 16.4 percent in the $1940-44$ cohort. The share claiming at 65 or older shrinks from 23.3 to 21.5 percent through the $1930-34$ cohort as the proportion claiming at 62 increases, and then reverses, growing rapidly to 37.1 percent by the $1940-44$ cohort.

For women, the portion claiming at 62 holds fairly steady at about 57 percent for the 1920-24, 1925-29, and 1930-34 cohorts (figure 4). It then shrinks for later cohorts, falling to 49 percent for the $1940-44$ cohort. The share claiming at 63 or 64 starts at around 22 percent in our sample, fluctuates somewhat, and ends up declining to 17.2 percent by the 1940-44 cohort. The share claiming at 65 or older grows steadily over 
time. It starts at 20.0 percent for the $1920-24$ cohort and reaches 33.8 percent for the 1940-44 cohort.

Figure 5 examines Social Security take-up in more detail, breaking down claiming after age 65 and comparing the distribution of claiming age by single year of birth. It reveals a steep decline in the share claiming at age 65 in the 1943 cohort and a corresponding spike in the share claiming at age 66. Compared to the 1942 birth cohort, the share claiming at age 65 fell 15 percentage points in the 1943 cohort (from 28 to 13 percent), while the share claiming at age 66 increased 14 percentage points (from 2 to 16 percent). Not coincidentally, the FRA first reached 66 (up from 65) for the 1943 birth cohort. This change appears to have substantially increased the number of beneficiaries who wait to age 66 to claim. The share claiming at other ages did not change much.

Figure 6 compares the share claiming within the first three months of turning 62 for men and women by single year of birth. That share is plotted against the year they turn 62 . The shaded bars in the figure identify recessionary years, as defined by the National Bureau of Economic Research. The sample extends through the 1947 birth cohort, which turned 62 in 2009.

For men, the share claiming within three months of turning 62 increases fairly steadily from 1978, when it stood at 29 percent, to 1995, when it peaked at 51 percent. It then fell fairly steadily, reaching a post-1995 low of 32 percent in 2007 before rebounding to 34 percent in 2008 and 35 percent in 2009 during the Great Recession. For women, the share claiming within three months of turning 62 fluctuated around 50 percent during the 1980s and early 1990s, before declining fairly steadily beginning in the mid-1990s. From 1994 to 2008, the share of 62-year-old eligible women claiming 
benefits within three months of their birthday fell from 53 to 39 percent. It increased somewhat to 40 percent in 2009 as the as unemployment rates soared.

A strong relationship between early claiming and economic recessions is not immediately evident in the figure. Age-62 claiming did increase for men in 2008 and remained relatively high in 2009 , as the economy contracted sharply and unemployment soared during the Great Recession. But women's claiming did not change much during the downturn. Early claiming among both men and women increased somewhat during the relatively mild 2001 recession, but not during the 1991-92 recession. These relatively small blips are overshadowed by the more substantial secular trend in claiming before and after the mid-1990s. Our hazards models explore this relationship in more depth.

\section{Claiming Ages by Cohort and Individual Characteristics}

Table 1 breaks down claiming behavior for men and women by educational attainment. The share claiming at 62 falls sharply with higher levels of education, and the share waiting until 65 or later increases. For example, among those in the 1940-44 birth cohort, men with only a high school diploma are about three-fifths more likely to claim retirement benefits at age 62 than men with more than a bachelor's degree. Moreover, men with more than a bachelor's degree are about three-fourths more likely to wait at least until age 65 to claim than those only a high school diploma, and nearly twice as likely as those who did not complete high school. The portion claiming at intermediate ages does not vary much by education (although well-educated women are somewhat more likely to claim at age 63 or 64 than those with limited education). 
Within each educational group for men and all but one educational group for women, we see the same pattern that prevails in the aggregate: age-62 claims increase over time through the 1930-34 cohort, and then decline. The exception is women without a high school diploma, who become less likely to claim at age 62 with each successive cohort. Also, cohort differences are less pronounced among men with more than a bachelor's degree. These very well educated men have always been relatively unlikely to claim early. It is noteworthy that both men and women with only a high school diploma as well as those who did not even complete high school were less likely to claim benefits at age 62 in the 1940-44 cohort than those born 10 years earlier. Between the 1930-34 cohorts and 1940-44 cohorts, age-62 claiming among high school graduates fell 11 percent for men and 13 percent for women. The trend toward delayed claiming has not been confined to well-educated adults.

Table 2 shows the distribution of claiming ages by quartiles of lifetime covered earnings received through age 61 . The pattern is consistent with observed differences by education, with the top earners claiming later than those with less earnings for both men and women. However, earnings differences in claiming are less pronounced than educational differences. In the 1940-44 birth cohort, for example, men in the bottom quarter of the lifetime earnings distribution are about a quarter more likely to claim at age 62 than those in the top quarter, while those in the top quarter are about a third more likely to wait at least until age 65 to claim than those near the bottom. Limited education appears to be a stronger predictor of early claiming than low earnings. Also, although those in the top earnings quintile generally claim later than those with lower earnings, 
claiming behavior does not vary much by earnings within the bottom three earnings quintiles.

The trend toward later claiming over the past 10 years is apparent for men in all earnings groups, but it has been less pronounced for those in the bottom quartile. For example, the share of men in the second earnings quartile claiming at age 62 is 27 percent higher for those in the 1930-34 cohort than those in the 1940-44 cohort, while the share claiming at age 65 or later is more than twice as high in the later cohort than the earlier one. For men in the bottom earnings quartile, the share claiming at age 65 or later increased 38 percent between the 1930-34 cohort and the 1940-44 cohort, still substantial but a much smaller increase than for higher earnings groups. Women's claiming ages barely changed at all over the past 10 years for those in the bottom earnings quartile, but they increased substantially for those earnings more. Between the 1930-34 and 1940-44 cohorts, women in the third earnings quartile claiming at age 62 fell 18 percent, while those claiming at age 65 or later increased 55 percent.

Table 3 shows age patterns of claiming by self-reported health status for respondents who were interviewed in the SIPP panels when they turned 62. People in better health generally claim later than those in worse health, although health-related differences in claiming are not as striking as education-related differences. In the 1940-44 birth cohort, more than 4 in 10 adults in excellent or very good health claim benefits at age 62 , and nearly 3 in 10 of those in fair or poor wealth wait at least until age 65 to collect. The share claiming at age 62 fell sharply over the past 10 years for those in excellent, very good, and good health, but it barely declined at all for those in fair or poor health. 


\section{Hazard Models for Men}

Table 4 shows the marginal effects from a series of discrete-time hazard models of initial Social Security benefit claims for men. Each column reports results from a different model that adds covariates to the previous specification. Standard errors are indicated in parentheses, with single asterisks indicating significance at the 5 percent level and double asterisks indicating significance at the 1 percent level. A hash (\#) indicates marginal significance at the 10 percent level.

Results indicate that men born between 1940 and 1944 claim Social Security significantly later than those born 10 years earlier (between 1930 and 1934). The later cohort is 0.9 percentage points less likely to claim each month than the earlier cohort, or about 16 percent less likely in relative terms. (The mean likelihood of claiming each month for men in our sample is 0.0562 .) This estimated difference does not change much when we add controls for education, health status, earnings, unemployment, or other factors.

Men born between 1945 and 1947, who turned age 62 between 2007 and 2009, are not significantly less likely to claim than those in the 1930-34 birth cohort when we do not control for other factors. However, they are substantially less likely to claim once we control for age, lifetime earnings, and the unemployment rate. When all factors in our model are held constant, men born from 1945 to 1947 are 2.0 percentage points (or 36 percent) less likely to claim than their counterparts born from 1930 to 1934.

Education and health status significantly influence men's claiming behavior. Men with a bachelor's degree are about 2 percentage points (or 36 percent) less likely to claim 
than those with only a high school diploma when we hold other factors constant, and those with more than a bachelor's degree are 3.3 percentage points (or 59 percent) less likely to claim. However, there is no significant difference between those without a high school diploma and those with no more than a high school diploma. Those in fair or poor health are 2.9 percentage points (or 52 percent) more likely to claim than men in excellent or very good health. Hispanics are significantly less likely than non-Hispanic whites to claim, but there is no significant difference in claiming behavior between African American and non-Hispanic white men. Marital status does not significantly affect men's claiming behavior either. Men are significantly more likely to claim in the next month when their monthly benefit would increase substantially by waiting that extra month to claim.

Unemployment boosts early claiming for men, although the effect is only marginally significant. A 1 percentage point increase in the state unemployment rate increases the likelihood of claiming Social Security benefits by 0.14 percentage points, or 2.5 percent, when other factors are held constant. Between 2007 and 2010, the national unemployment rate for men age 55 to 61 increased about 5 percentage points, from 3.2 to 8.1 percent (Urban Institute Program on Retirement Policy 2011c). Applying this increase to our model estimates implies that the Great Recession boosted men's Social Security claiming by about 0.7 percentage point, or 12 percent.

To examine whether benefit claiming trends and business cycle effects for men vary by education, we stratify the sample by education and estimate the hazard models separately for men with limited education (high school dropouts and high school graduates who never attended college) and for well-educated men (those who attended 
college, including those with associate's, bachelor's, or advanced degrees as well as those who never received a degree.) Table 5 reports results from our last specification that includes the full set of controls. Men with no more a high school education are significantly more likely to claim Social Security retirement benefits when unemployment is relatively high than when it is lower, but well-educated men's claiming behavior is not significantly correlated with the state unemployment rate. A 1 percentage point increase in the state unemployment rate is associated with a 0.4 percentage point increase in the likelihood each month that men who never attended college claim benefits, a relative increase of 6 percent. This estimate implies that the Great Recessionwhich boosted unemployment rates among men age 55 to 61 with no more than a high school diploma by about 7 percentage points between 2007 and 2010 (Urban Institute Program on Retirement Policy 2011d)—increased claiming by about 2.8 percentage points, or 40 percent, for men with limited education. The estimated impact for welleducated men is virtually zero. Unemployment's large effect on claiming for poorly educated men but not for well-educated men is consistent with less-educated men's generally higher rates of job loss during economic downturns (Johnson and Mommaerts 2011).

Although well-educated men remain less likely to claim retirement benefits each month than those with more limited education, early claiming has fallen somewhat more rapidly over the past 10 years among men who did not attend college. When we control for other factors, less-educated men born between 1940 and 1944 are 1.3 percentage points less likely to claim benefits each moth than their counterparts in the 1930-34 birth 
cohort. By contrast, we find no significant difference in claiming behavior between the 1930-34 and 1940-44 cohorts among men who attended college.

\section{Hazard Models for Women}

Table 6 reports results for women. As with men, women born between 1940 and 1944 are significantly less likely to claim Social Security benefits than those born between 1930 and 1934. Women born in the later cohort are 1.3 percentage points (or 21 percent) less likely to claim each month than those born in the earlier cohort. (The mean likelihood of claiming each month for women in our sample is 0.0626 .) The estimated difference between the two cohorts is similar when we hold our full set of controls constant, including age. ${ }^{2}$ Women born 1945 to 1947 are 18 percent less likely to claim each month than women in the 1930-34 birth cohort when those factors are held constant. Women born 1921 to 1924 are 3.6 percentage points (or 58 percent) more likely to claim benefits each month than those in the 1930-34 cohort. However, this difference diminishes as more controls are added to the model, suggesting that changes over time in education, women's marital status, age, and health status explain part of the delay in claiming for women between the early 1980s and early 1990s.

Education, health, and marital status all affect women's claiming behavior. Relative to women with only a high school diploma, those with a bachelor's degree are 1.9 percentage points (or 30 percent) less likely to claim benefits each month, and those more than a bachelor's degree are 3.4 percentage points (or 54 percent) less likely to

\footnotetext{
${ }^{2}$ However, the difference in claiming age between the 1930-34 cohort and the 1940-44 cohort is insignificant when we control for lifetime earnings, the unemployment rate, health status, and demographic characteristics other than age.
} 
claim. Health problems encourage women to claim early; those in fair or poor health are 1.6 percentage points (or 26 percent) more likely to claim than those in excellent or very good health. Unlike for men, women's marital status has large effects on claiming. Never married women are 2.6 percentage points (or 42 percent) less likely to claim than married women, while divorced, separated, and widowed women are 4.7 percentage points (or 75 percent) less likely to claim. There are no significant differences in claiming between Hispanic, African American, and non-Hispanic white women. As with men, women are significantly more likely to claim the next month when their monthly benefits would increase substantially by waiting that extra month to claim.

Interestingly, the business cycle does not appear to affect women's claiming behavior much. The coefficient on the state unemployment rate in our model is small and statistically insignificant. We do not find any significant relationship between claiming and the unemployment rate for women when we stratify the sample by education, either. For both women with no more than a high school education and those who attended college, the estimated coefficient on the state unemployment rate variable is insignificant (table 7). This finding stands in contrast to our result for men.

Estimating separate models by education reveals that the trend toward later claiming among recent cohorts is much more pronounced among women who never attended college than among those with more education. For women who attended college, those born between 1940 and 1944 are only slightly less likely to claim benefits each month than those in the 1930 to 1934 cohort, when other factors are held constant. Differences in claiming between the 1945 to 1947 cohort and the 1930 to 1934 cohort are 
even smaller. For women with no than a high school diploma, claiming differences between the 1930 to 1934 cohort and later cohorts are substantial.

\section{Conclusions}

The share of adults claiming Social Security retirement benefits at age 62 fell sharply over the past 10 years. Early claiming has become less common for men and women of all educational groups, not just for well-educated adults. This decline is especially noteworthy for men because it followed a 10 -year increase in early claiming. Nonetheless, early claiming remains commonplace. Nearly half of eligible adults born between 1940 and 1944 claimed Social Security retirement benefits at age 62. Early takeup is even more prevalent among women, adults with limited education, and those with health problems.

Less-educated men tend to claim earlier when unemployment is high than when the labor market is stronger. The likelihood that they claim benefits each month increases 6 percent with every 1 percentage point increase in the unemployment rate. Deep recessions, then, substantially promote early retirement. The 7 percentage point rise in the unemployment rate between 2007 and 2010 among men age 55 to 61 with no than a high school diploma increased their Social Security claiming hazard by 40 percent. However, high unemployment does not promote early claiming by women or men who attended college, who are much less likely to lose their jobs during economic downturns than lesseducated men.

The claiming age matters because it affects retirement security. Claiming later substantially increases monthly Social Security retirement benefits. Even if lifetime 
benefits do not increase much because late claimers receive fewer payments than they would if they claimed earlier, later claiming can boost total retirement income because most people continue to work as they wait to receive benefits. Various Social Security parameters, such as the FRA, DRC, and early entitlement age, can be altered to promote later claiming. Social Security provides an important safety net for older workers who lose their jobs, but early claiming during economic downturns can significantly reduce retirement income.

\section{References}

Allison, Paul D. 1984. Event History Analysis. Beverly Hills, CA: Sage.

Autur, David H., and Mark G. Duggan. 2003. "The Rise in the Disability Roles and the Decline in Unemployment." Quarterly Journal of Economics 118(1): 157-206.

Blau, David M., and Donna B. Gilleskie. 2001. "Retiree Health Insurance and the Labor Force Behavior of Older Men in the 1990s." Review of Economics and Statistics 83(1): 64-80.

Blau, David M., and Ryan M. Goodstein. 2010. "Can Social Security Explain Trends in Labor Force Participation of Older Men in the United States?" Journal of Human Resources 45(2): 328-63.

Bureau of Labor Statistics. 2010. National Compensation Survey: Employee Benefits in the United States, March 2010. Washington, D.C.: U.S. Department of Labor.

Burkhauser, Richard V., Kenneth A. Couch, and John W. Phillips. 1996. "Who Takes Early Social Security Benefits? The Economic and Health Characteristics of Early Beneficiaries." The Gerontologist 36(6): 789-99.

Butrica, Barbara A., and Richard W. Johnson. 2012. "What Is the Short-Term Financial Impact of Job Loss for Older Workers?" Washington, DC: The Urban Institute.

Coile, Courtney C., Peter Diamond, Jonathan Gruber, and Alain Jousten. 2002. "Delays in Claiming Social Security Benefits." Journal of Public Economics 84(3): 35785. 
Czajka, John L., James Mabli, and Scott Cody. 2008. "Sample Loss and Survey Bias in Estimates of Social Security Beneficiaries: A Tale of Two Surveys." Washington, DC: Mathematica Policy Research, Inc.

Favreault, Melissa M., and Austin Nichols. 2011. "Immigrant Diversity and Social Security: Recent Patterns and Future Prospects." Washington, DC: The Urban Institute.

Friedberg, Leora. 2000. "The Labor Supply Effects of the Social Security Earnings Test." Review of Economics and Statistics 82(1): 48-63.

Friedberg, Leora, and Anthony Webb. 2005. "Retirement and the Evolution of Pension Structure." Journal of Human Resources 40(2): 281-308.

Friedberg, Leora, Michael Owyang, and Anthony Webb. 2008. "Identifying Local Differences in Retirement Patterns." CRR WP 2008-18. Chestnut Hill, MA: Center for Retirement Research at Boston College.

Gruber, Jonathan, and Peter Orszag. 2003. "Does the Social Security Earnings Test Affect Labor Supply and Benefits Receipt?” National Tax Journal 56(4): 755-73.

Haider, Steven J., and David S. Loughran. 2008. "The Effect of the Social Security Earnings Test on Male Labor Supply: New Evidence from Survey and Administrative Data." Journal of Human Resources 43(1): 57-87.

Hurd, Michael D., James P. Smith, and Julie M. Zissimopoulos. 2002. "The Effects of Subjective Survival on Retirement and Social Security Claiming." MRRC Working Paper 2002-021. Ann Arbor, MI: Michigan Retirement Research Center, University of Michigan.

Hutchens, Robert. 1999. "Social Security Benefits and Employer Behavior: Evaluating Social Security Early Retirement Benefits as a Form of Unemployment Insurance.” International Economic Review 49(3): 659-78.

Johnson, Richard W. 2007. "What Happens to Health Benefits after Retirement?" Chestnut Hill, MA: Center for Retirement Research at Boston College.

—. Forthcoming. "Increasing Social Security's Early Eligibility Age While Protecting Vulnerable Workers: What Are the Options?" Washington, DC: AARP.

Johnson, Richard W., and Corina Mommaerts. 2011. "Age Differences in Job Loss, Job Search, and Reemployment.” Washington, DC: The Urban Institute.

Johnson, Richard W., Amy J. Davidoff, and Kevin Perese. 2003. "Health Insurance Costs and Early Retirement Decisions." Industrial and Labor Relations Review 56(4): $716-29$. 
Kaiser Family Foundation and Health Research and Educational Trust. 2009. Employer Health Benefits 2009 Annual Survey. Washington, DC: Kaiser Family Foundation and Health Research and Educational Trust.

Laschober, Mary. 2004. "Trends in Medicare Supplemental Insurance and Prescription Drug Benefits, 1996-2001.” Menlo Park, CA: Henry J. Kaiser Family Foundation.

Li, Xiaoyan, Michael Hurd, and David S. Loughran. 2008. "The Characteristics of Social Security Beneficiaries Who Claim Benefits at the Early Entitlement Age." Washington, DC: AARP.

Lumsdaine, Robin L., James H. Stock, and David A. Wise. 1996. "Retirement Incentives: The Interaction between Employer-Provided Pensions, Social Security, and Retiree Health Benefits." In The Economic Effects of Aging in the United States and Japan, edited by Michael D. Hurd and Naohiro Yashiro (261-93). Chicago: University of Chicago Press.

Mermin, Gordon B.T., Richard W. Johnson, and Dan Murphy. 2007. "Why Do Boomers Plan To Work Longer?” Journal of Gerontology: Social Sciences 62B(5): S28694.

Munnell, Alicia H., Mauricio Soto, Robert K. Triest, and Natalia A. Zhivan. 2008. "How Much Do State Economics and Other Characteristics Affect Labor Force Participation of Older Workers?" CRR WP 2008-12. Chestnut Hill, MA: Center for Retirement Research at Boston College.

National Center for Health Statistics. 2011. "Health Data Interactive." http://www.cdc.gov/nchs/hdi.htm.

Pension and Welfare Benefits Administration. 2001-2002. "Private Pension Plan Bulletin: Abstract of 1998 Form 5500 Annual Reports.” Washington, DC: U.S. Department of Labor.

Rogowski, Jeannette, and Lynn Karoly. 2000. "Health Insurance and Retirement Behavior: Evidence from the Health and Retirement Survey." Journal of Health Economics 19(4): 529-39.

Samwick, Andrew A. 1998. "New Evidence on Pensions, Social Security, and the Timing of Retirement." Journal of Public Economics 70(2): 207-36.

Schirle, Tammy. 2008. "Why Have the Labor Force Participation Rates of Older Men Increased since the Mid-1990s?” Journal of Labor Economics 26(4): 549-94.

Sears, James, and Kalman Rupp. 2003. "Exploring Social Security Payment History Matched with the Survey of Income and Program Participation." Paper presented 
at the Federal Committee on Statistical Methodology Research Conference, Washington, DC (November 18).

Social Security Administration. 2011. Annual Statistical Supplement to the Social Security Bulletin, 2010. Washington, DC: Social Security Administration.

Song, Jae G. 2004. "Evaluating the Initial Impact of Eliminating the Retirement Earnings Test." Social Security Bulletin 65(1): 1-15.

Song, Jae G., and Joyce Manchester. 2007. "New Evidence on Earnings and Benefit Claims Following Changes in the Retirement Earnings Test in 2000." Journal of Public Economics 91(3-4): 669-700.

Stock, James H., and David A. Wise. 1990. "Pensions, the Option Value of Work, and Retirement." Econometrica 58(5): 1151-80.

Tran, Bac V. 2004. "The Impact of the Repeal of the Retirement Earnings Test on the Labor Supply of Older Workers." College Park, MD: University of Maryland.

Urban Institute Program on Retirement Policy. 2011a. "Female Labor Force Participation Rates by Age, 1948-2010." Washington, DC: The Urban Institute. http://www.urban.org/retirement policy/datawarehouse/olderworkers.cf $\underline{\text { m. }}$

-----. 2011b. “Male Labor Force Participation Rates by Age, 1948-2010.” Washington, DC: The Urban Institute. http://www.urban.org/retirement policy/datawarehouse/olderworkers.cf $\underline{\mathrm{m}}$.

—. 2011c. "Male Unemployment Rates by Age, 1948-2010." Washington, DC: The Urban Institute. http://www.urban.org/retirement policy/datawarehouse/upload/t19.pdf.

—. 2011d. "Older Men's Unemployment Rates by Age and Education, 1983-2010." Washington, DC: The Urban Institute. http://www.urban.org/retirement policy/datawarehouse/upload/t21.pdf. 
Figure 1. Social Security Benefit Awards and DI Applications, 1978-2010

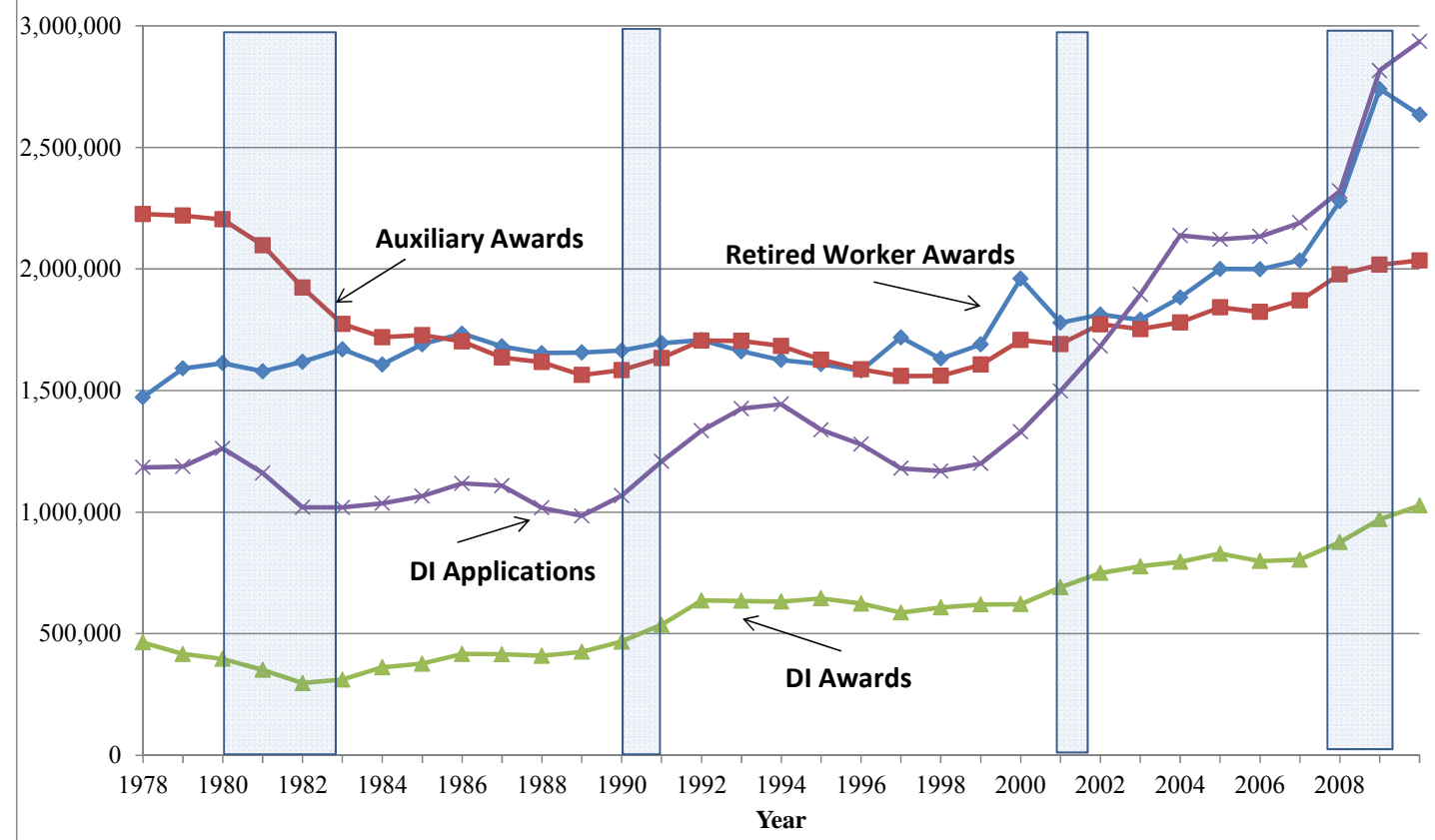

Source: Social Security Administration (2011).

Note: Shaded areas indicate recessions, as defined by the National Bureau of Economic Research.

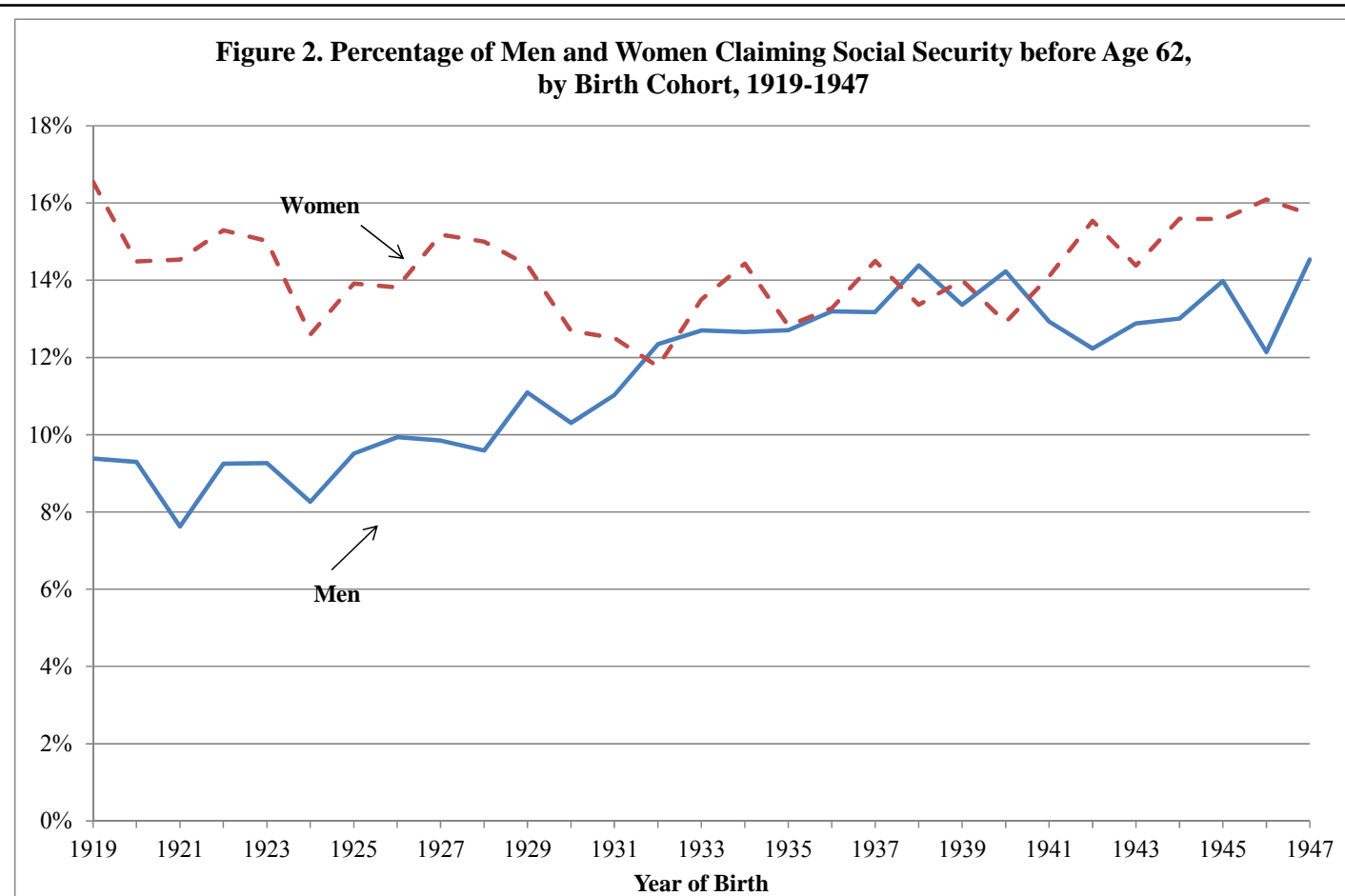

Source: Authors' estimates from the 1984 to 2008 SIPP panels linked to administrative benefit records.

Note: The sample is restricted to men and women who claimed before age 62 or had accumulated 40 quarters of covered earnings by age 62 . 

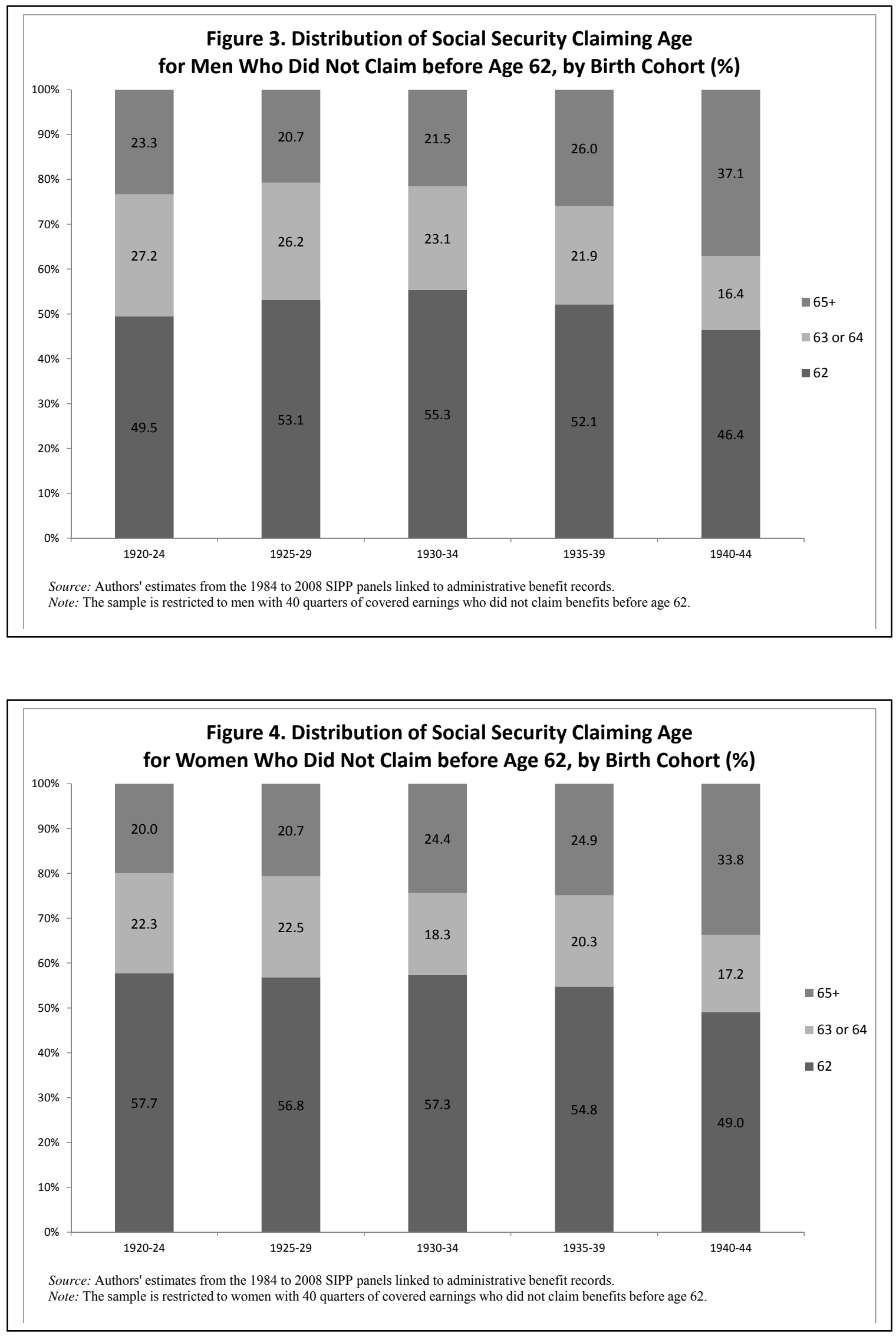

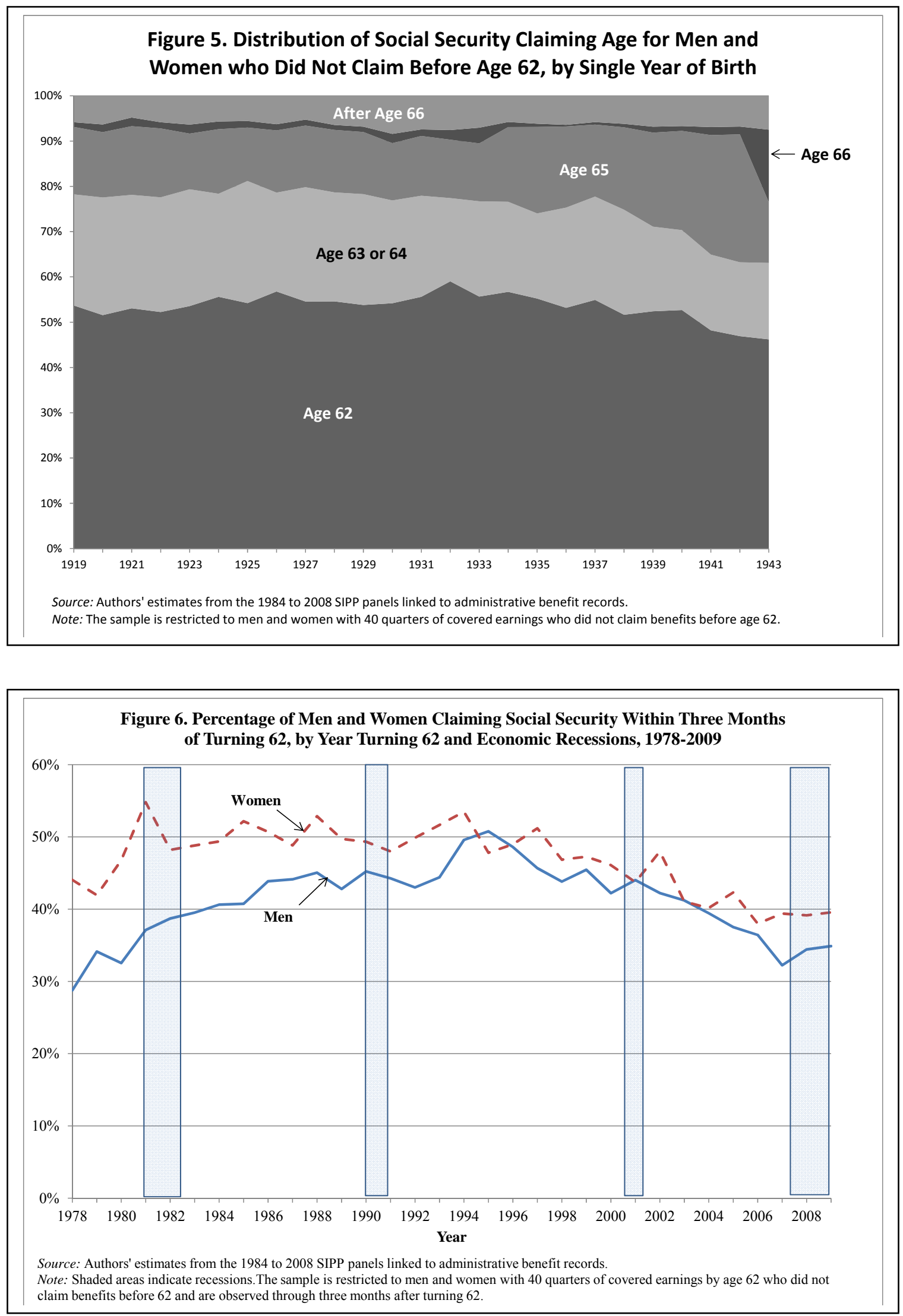
Table 1. Distribution of Social Security Claiming Age by Education, Birth Cohort, and Sex (\%)

\begin{tabular}{|c|c|c|c|c|c|c|}
\hline & \multicolumn{3}{|c|}{ Men } & \multicolumn{3}{|c|}{ Women } \\
\hline & 62 & 63 or 64 & $65+$ & 62 & 63 or 64 & $65+$ \\
\hline \multicolumn{7}{|c|}{ Not High School Grad } \\
\hline $1920-24$ & 58.1 & 27.5 & 14.4 & 65.9 & 17.9 & 16.2 \\
\hline $1925-29$ & 60.8 & 24.9 & 14.3 & 61.3 & 21.2 & 17.5 \\
\hline $1930-34$ & 62.9 & 20.9 & 16.2 & 60.4 & 13.9 & 25.7 \\
\hline 1935-39 & 58.8 & 20.5 & 20.7 & 58.3 & 15.9 & 25.8 \\
\hline $1940-44$ & 55.5 & 16.8 & 27.7 & 57.4 & 14.8 & 27.8 \\
\hline \multicolumn{7}{|c|}{ High School Grad } \\
\hline $1920-24$ & 53.3 & 26.2 & 20.5 & 58.8 & 23.1 & 18.1 \\
\hline $1925-29$ & 58.1 & 25.5 & 16.4 & 60.3 & 21.7 & 18.1 \\
\hline 1930-34 & 59.8 & 22.9 & 17.4 & 62.7 & 17.2 & 20.1 \\
\hline $1935-39$ & 58.8 & 22.4 & 18.8 & 59.2 & 19.9 & 20.9 \\
\hline $1940-44$ & 53.1 & 16.7 & 30.2 & 54.3 & 15.6 & 30.1 \\
\hline \multicolumn{7}{|l|}{ Some College } \\
\hline $1920-24$ & 46.8 & 28.9 & 24.4 & 49.1 & 25.0 & 25.9 \\
\hline $1925-29$ & 52.9 & 26.0 & 21.1 & 53.2 & 22.9 & 24.0 \\
\hline $1930-34$ & 56.7 & 23.1 & 20.2 & 51.4 & 22.1 & 26.4 \\
\hline $1935-39$ & 52.3 & 22.3 & 25.4 & 52.8 & 20.7 & 26.5 \\
\hline $1940-44$ & 48.6 & 18.1 & 33.3 & 47.9 & 18.2 & 33.9 \\
\hline \multicolumn{7}{|c|}{ Bachelor's Degree } \\
\hline $1920-24$ & 34.5 & 27.1 & 38.4 & 46.4 & 27.3 & 26.2 \\
\hline $1925-29$ & 38.0 & 32.1 & 29.9 & 46.5 & 25.3 & 28.3 \\
\hline $1930-34$ & 49.4 & 24.2 & 26.4 & 49.1 & 19.9 & 31.0 \\
\hline $1935-39$ & 43.6 & 21.8 & 34.6 & 46.9 & 25.3 & 27.8 \\
\hline $1940-44$ & 37.5 & 16.6 & 45.9 & 39.4 & 20.5 & 40.1 \\
\hline \multicolumn{7}{|c|}{ Advanced Degree } \\
\hline $1920-24$ & 31.0 & 26.6 & 42.4 & 42.7 & 25.5 & 31.9 \\
\hline $1925-29$ & 33.3 & 25.7 & 40.9 & 39.5 & 29.1 & 31.5 \\
\hline $1930-34$ & 36.1 & 26.3 & 37.5 & 43.1 & 23.5 & 33.4 \\
\hline $1935-39$ & 36.1 & 22.1 & 41.9 & 41.7 & 23.6 & 34.7 \\
\hline $1940-44$ & 33.0 & 13.4 & 53.7 & 35.3 & 19.3 & 45.4 \\
\hline
\end{tabular}

Source: Authors' estimates from the 1984 to 2008 SIPP panels linked to administrative benefit records. Note: The sample is restricted to adults with 40 quarters of covered earnings who did not claim Social Security before age 62 . 
Table 2. Distribution of Social Security Claiming Age by Lifetime Earnings Quartile, Birth Cohort, and Sex (\%)

\begin{tabular}{|c|c|c|c|c|c|c|}
\hline & \multicolumn{3}{|c|}{ Men } & \multicolumn{3}{|c|}{ Women } \\
\hline & 62 & 63-64 & $65+$ & 62 & $63-64$ & $65+$ \\
\hline \multicolumn{7}{|l|}{ Bottom } \\
\hline $1925-29$ & 54.4 & 23.2 & 22.4 & 57.8 & 20.2 & 22.1 \\
\hline $1930-34$ & 53.9 & 20.6 & 25.5 & 54.3 & 15.2 & 30.6 \\
\hline $1935-39$ & 53.1 & 18.3 & 28.5 & 54.1 & 16.5 & 29.4 \\
\hline $1940-44$ & 48.2 & 16.4 & 35.3 & 53.2 & 16.8 & 30.0 \\
\hline \multicolumn{7}{|l|}{ Second } \\
\hline $1925-29$ & 59.3 & 25.3 & 15.4 & 65.5 & 18.0 & 16.5 \\
\hline $1930-34$ & 61.6 & 23.7 & 14.7 & 67.5 & 15.5 & 17.0 \\
\hline $1935-39$ & 52.9 & 26.3 & 20.8 & 63.4 & 18.1 & 18.5 \\
\hline $1940-44$ & 48.6 & 18.6 & 32.8 & 56.3 & 17.5 & 26.2 \\
\hline \multicolumn{7}{|l|}{ Third } \\
\hline $1925-29$ & 58.7 & 25.1 & 16.2 & 56.3 & 24.4 & 19.3 \\
\hline $1930-34$ & 60.5 & 23.7 & 15.8 & 56.3 & 20.7 & 23.1 \\
\hline $1935-39$ & 57.9 & 23.2 & 18.9 & 52.6 & 22.5 & 24.9 \\
\hline $1940-44$ & 52.2 & 16.3 & 31.5 & 46.1 & 18.2 & 35.7 \\
\hline \multicolumn{7}{|l|}{ Top } \\
\hline $1925-29$ & 41.2 & 30.5 & 28.3 & 48.7 & 26.7 & 24.6 \\
\hline $1930-34$ & 46.5 & 24.2 & 29.2 & 51.6 & 21.3 & 27.1 \\
\hline $1935-39$ & 45.3 & 20.1 & 34.7 & 49.7 & 23.6 & 26.7 \\
\hline $1940-44$ & 37.8 & 14.7 & 47.5 & 41.8 & 16.4 & 41.8 \\
\hline
\end{tabular}

Source: Authors' estimates from the 1984 to 2008 SIPP panels linked to administrative benefit records.

Note: Lifetime earnings are measured as of age 61, and expressed in constant (price-adjusted) dollars. The sample is restricted to adults with 40 quarters of covered earnings who did not claim Social Security before age 62 . 
Table 3. Distribution of Social Security Claiming Age by Health Status, Birth Cohort, and Sex (\%)

\begin{tabular}{cccc}
\hline & \multicolumn{3}{c}{ All } \\
\cline { 2 - 4 } & $\mathbf{6 2}$ & $\mathbf{6 3}$ or $\mathbf{6 4}$ & $\mathbf{6 5 +}$ \\
\hline Excellent or Very Good & & & \\
$1925-29$ & 47.0 & 28.7 & 24.3 \\
$1930-34$ & 51.7 & 23.8 & 24.5 \\
$1935-39$ & 48.4 & 20.5 & 31.1 \\
$1940-44$ & 42.9 & 17.3 & 39.8 \\
Good & & & \\
$1925-29$ & 59.6 & 21.2 & 19.2 \\
$1930-34$ & 57.9 & 20.4 & 21.6 \\
$1935-39$ & 58.3 & 17.9 & 23.8 \\
$1940-44$ & 49.8 & 16.4 & 33.8 \\
Fair or Poor & & & \\
$1925-29$ & 59.6 & 15.3 & 25.1 \\
$1930-34$ & 61.3 & 16.5 & 22.2 \\
$1935-39$ & 62.0 & 13.2 & 24.7 \\
$1940-44$ & 60.5 & 11.5 & 28.0 \\
\hline
\end{tabular}

Source: Authors' estimates from the 1984 to 2008 SIPP panels linked to administrative benefit records. Note: The sample is restricted to adults with 40 quarters of covered earnings who did not claim Social Security before age 62 . 
Table 4. Marginal Impact on the Likelihood of Claiming Social Security Benefits, Men

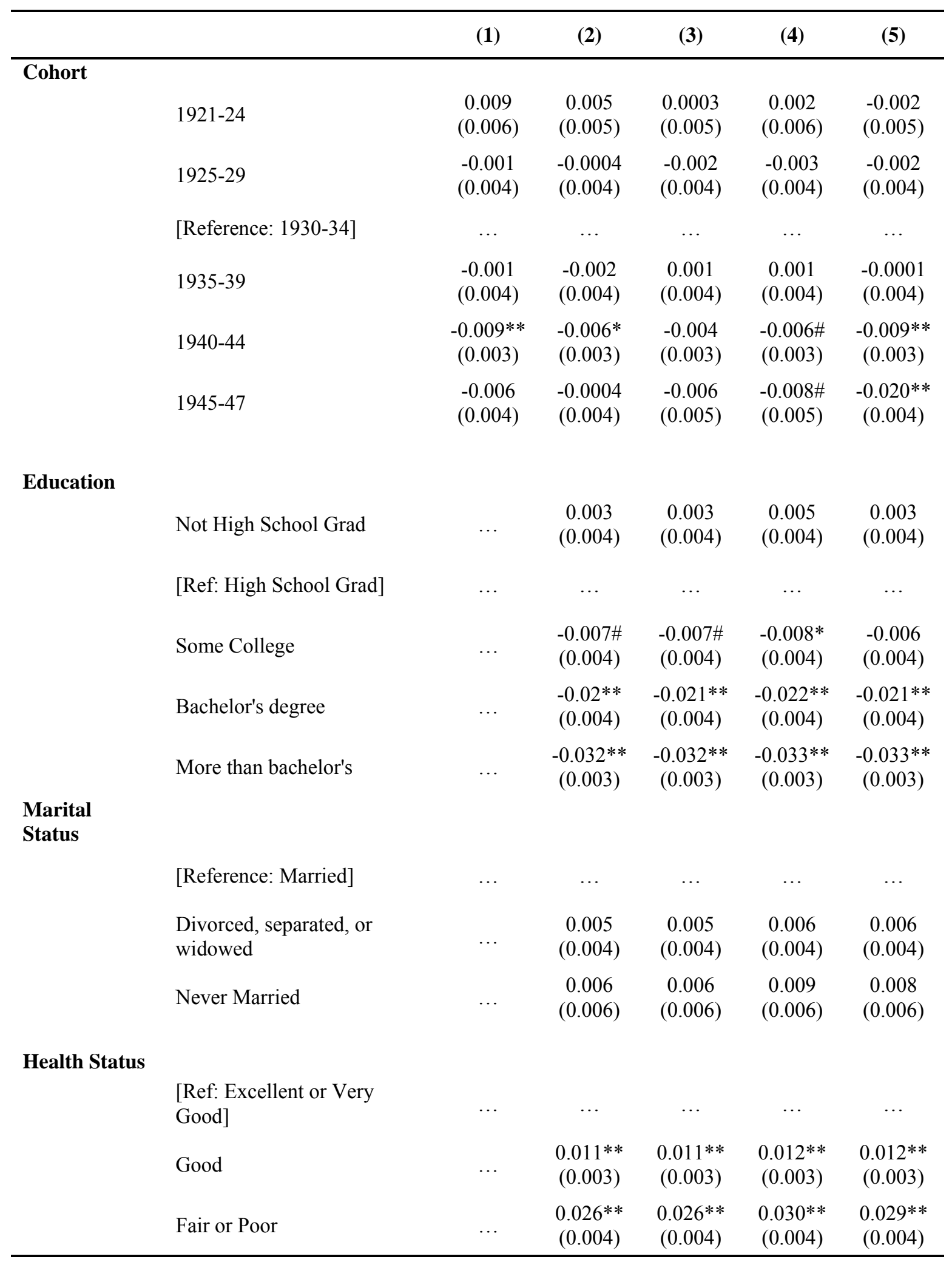

(continued) 
Table 4 (continued).

(1)

(2)

(3)

(4)

(5)

Race

[Ref: White, Non-Hispanic]

Black, Non-Hispanic

$$
\begin{array}{ccccc}
\ldots & -0.0004 & 0.00002 & 0.002 & 0.001 \\
& (0.004) & (0.004) & (0.005) & (0.004)
\end{array}
$$

Hispanic

$\begin{array}{ccccc} & - & - & 0.021^{* *} & -0.019^{* *} \\ & 0.022^{* *} & 0.023^{* *} & -0.0 .005) & (0.005)\end{array}$

Other, Non-Hispanic

$\begin{array}{cccc}-0.02 * * & -0.02 * * & -0.016^{* *} & -0.015^{*} \\ (0.005) & (0.005) & (0.006) & (0.006)\end{array}$

State-Level Unemployment Rate

Log of Lifetime Earnings at Age 61

$\begin{array}{ccccc} & -0.02 * * & -0.02 * * & -0.016^{* *} & -0.015^{*} \\ & (0.005) & (0.005) & (0.006) & (0.006)\end{array}$

Change in Monthly Social Security Benefits from Delaying Claiming by One Month

\begin{tabular}{|c|c|c|c|}
\hline$\ldots$ & $\begin{array}{c}0.002 * * \\
(0.001)\end{array}$ & $\begin{array}{c}0.003^{* *} \\
(0.001)\end{array}$ & $\begin{array}{l}0.014 \# \\
(0.001)\end{array}$ \\
\hline$\ldots$ & $\cdots$ & $\begin{array}{l}0.004 * \\
(0.002)\end{array}$ & $\begin{array}{l}0.003 \# \\
(0.002)\end{array}$ \\
\hline$\cdots$ & $\cdots$ & $\begin{array}{l}0.001 * * \\
(0.0001)\end{array}$ & $\begin{array}{l}0.001^{* *} \\
(0.0001)\end{array}$ \\
\hline & & $\begin{array}{c}-0.045^{* *} \\
(0.005)\end{array}$ & $\begin{array}{c}-0.060^{* *} \\
(0.005)\end{array}$ \\
\hline
\end{tabular}

Whether First Month of Eligibility

Age

[Reference: 62]

63

64

65 or older

$\mathrm{N}$

Pseudo R-squared

Mean of dependent variable

\begin{tabular}{ccccc}
$\ldots$ & $\ldots$ & $\ldots$ & $\ldots$ & $\ldots$ \\
$\ldots$ & $\ldots$ & $\ldots$ & $\ldots$ & $-0.065^{* *}$ \\
& & & & $(0.002)$ \\
$\ldots$ & $\ldots$ & $\ldots$ & $\ldots$ & $-0.063^{* *}$ \\
& & & & $(0.003)$ \\
$\ldots$ & $\ldots$ & $\ldots$ & $\ldots$ & $0.119^{*}$ \\
37,912 & 37,912 & 37,912 & 37,912 & 37,912 \\
.001 & .0157 & .0163 & .0266 & .0774 \\
.0562 & .0562 & .0562 & .0562 & .0562 \\
\hline
\end{tabular}

Source: Authors' computations from the 1984-2008 SIPP panels linked to administrative records, spanning the years 1983 to 2009 .

Note: Standard errors are in parentheses. The models are estimated on a person-month sample of men age 61 and 11 months or older with 40 years of covered earnings who have not yet claimed Social Security benefits.

$* * \mathrm{p}<.01 ; * .01 \leq \mathrm{p}<.05 ; \# .05 \leq \mathrm{p}<.10$ 
Table 5. Differential Effects by Educational Attainment on the Likelihood of Claiming Social Security Benefits, Men

\begin{tabular}{lll}
\hline & $\begin{array}{c}\text { Never } \\
\text { Attended } \\
\text { College }\end{array}$ & $\begin{array}{c}\text { Attended } \\
\text { College }\end{array}$ \\
\hline State Level Unemployment Rate & $0.004^{* *}$ & -0.001 \\
& $(0.001)$ & $(0.001)$
\end{tabular}

\section{Cohort}

$\begin{array}{lcc}1921-24 & 0.0001 & -0.009 \\ & (0.008) & (0.008) \\ 1925-29 & -0.004 & -0.001 \\ & (0.006) & (0.006) \\ \text { [Reference: 1930-34] } & \ldots & \ldots \\ & & \\ 1935-39 & -0.007 & -0.002 \\ & (0.007) & (0.005) \\ 1940-44 & -0.013^{*} & -0.006 \\ & (0.005) & (0.004) \\ 1945-47 & -0.018^{*} & -0.016^{* *} \\ & (0.008) & (0.005) \\ & & \\ & 16,900 & 21,012 \\ & 0.0795 & 0.0626 \\ & 0.0693 & 0.0455\end{array}$

Source: Authors' computations from the 1984-2008 SIPP panels linked to administrative records, spanning the years 1983 to 2009 .

Note: Estimates show the marginal impact on the likelihood of claiming Social Security benefits. Standard errors are in parentheses. The models are estimated on a person-month sample of men age 61 and 11 months or older with 40 years of covered earnings who have not yet claimed Social Security benefits. In addition to the variables included in the table, the models also control for education, marital status, race, health status, age, natural log of lifetime earnings at age 61, the change in monthly Social Security benefits from delaying claiming by one month. and month of first eligibility for retirement benefits.

$* * \mathrm{p}<.01 ; * .01 \leq \mathrm{p}<.05 ; \# .05 \leq \mathrm{p}<.10$ 
Table 6. Marginal Impact on the Likelihood of Claiming Social Security Benefits, Women

\begin{tabular}{|c|c|c|c|c|c|}
\hline & (1) & (2) & (3) & (4) & (5) \\
\hline \multicolumn{6}{|l|}{ Cohort } \\
\hline $1921-24$ & $\begin{array}{c}0.036^{* *} \\
(0.008)\end{array}$ & $\begin{array}{c}0.022 * * \\
(0.007)\end{array}$ & $\begin{array}{c}0.021 * * \\
(0.007)\end{array}$ & $\begin{array}{c}0.024 * * \\
(0.008)\end{array}$ & $\begin{array}{c}0.016 * \\
(0.007)\end{array}$ \\
\hline $1925-29$ & $\begin{array}{c}-0.007 \\
(0.005)\end{array}$ & $\begin{array}{c}-0.004 \\
(0.005)\end{array}$ & $\begin{array}{l}-0.005 \\
(0.005)\end{array}$ & $\begin{array}{c}-0.005 \\
(0.005)\end{array}$ & $\begin{array}{c}-0.004 \\
(0.005)\end{array}$ \\
\hline [Reference: 1930-34] & $\ldots$ & $\ldots$ & $\ldots$ & $\ldots$ & $\ldots$ \\
\hline $1935-39$ & $\begin{array}{c}-0.009 * \\
(0.004)\end{array}$ & $\begin{array}{l}-0.005 \\
(0.004)\end{array}$ & $\begin{array}{c}-0.004 \\
(0.004)\end{array}$ & $\begin{array}{c}-0.005 \\
(0.004)\end{array}$ & $\begin{array}{c}-0.006 \\
(0.004)\end{array}$ \\
\hline $1940-44$ & $\begin{array}{c}-0.013 * * \\
(0.003)\end{array}$ & $\begin{array}{c}-0.005 \\
(0.004)\end{array}$ & $\begin{array}{c}-0.004 \\
(0.004)\end{array}$ & $\begin{array}{c}-0.006 \\
(0.004)\end{array}$ & $\begin{array}{c}-0.009 * \\
(0.004)\end{array}$ \\
\hline $1945-47$ & $\begin{array}{c}0.002 \\
(0.005)\end{array}$ & $\begin{array}{c}0.007 \\
(0.005)\end{array}$ & $\begin{array}{c}0.006 \\
(0.006)\end{array}$ & $\begin{array}{c}0.005 \\
(0.006)\end{array}$ & $\begin{array}{l}-0.011 * \\
(0.005)\end{array}$ \\
\hline \multicolumn{6}{|l|}{ Education } \\
\hline Not High School Grad & $\cdots$ & $\begin{array}{c}0.01 * \\
(0.005)\end{array}$ & $\begin{array}{c}0.01 * \\
(0.005)\end{array}$ & $\begin{array}{c}0.013 * * \\
(0.005)\end{array}$ & $\begin{array}{l}0.010 * \\
(0.005)\end{array}$ \\
\hline [Ref: High School Grad] & $\cdots$ & $\ldots$ & $\ldots$ & $\ldots$ & $\ldots$ \\
\hline Some College & $\cdots$ & $\begin{array}{c}-0.016 * * \\
(0.003)\end{array}$ & $\begin{array}{c}-0.016 * * \\
(0.003)\end{array}$ & $\begin{array}{c}-0.017 * * \\
(0.003)\end{array}$ & $\begin{array}{c}-0.015^{* *} \\
(0.003)\end{array}$ \\
\hline bachelor's Degree & $\cdots$ & $\begin{array}{c}-0.018 * * \\
(0.004)\end{array}$ & $\begin{array}{c}-0.018 * * \\
(0.004)\end{array}$ & $\begin{array}{c}-0.019 * * \\
(0.004)\end{array}$ & $\begin{array}{c}-0.019 * * \\
(0.004)\end{array}$ \\
\hline More than bachelor's & $\ldots$ & $\begin{array}{c}-0.032 * * \\
(0.004)\end{array}$ & $\begin{array}{c}-0.032 * * \\
(0.004)\end{array}$ & $\begin{array}{c}-0.035^{* *} \\
(0.004)\end{array}$ & $\begin{array}{c}-0.034 * * \\
(0.004)\end{array}$ \\
\hline \multicolumn{6}{|l|}{ Marital Status } \\
\hline [Reference: Married] & $\cdots$ & $\cdots$ & $\cdots$ & $\cdots$ & $\cdots$ \\
\hline $\begin{array}{l}\text { Divorced, separated, or } \\
\text { widowed }\end{array}$ & $\cdots$ & $\begin{array}{c}-0.048 * * \\
(0.003)\end{array}$ & $\begin{array}{c}-0.048^{* *} \\
(0.003)\end{array}$ & $\begin{array}{c}-0.050 * * \\
(0.003)\end{array}$ & $\begin{array}{c}-0.047 * * \\
(0.003)\end{array}$ \\
\hline Never Married & $\cdots$ & $\begin{array}{c}-0.026 * * \\
(0.006)\end{array}$ & $\begin{array}{c}-0.026 * * \\
(0.006)\end{array}$ & $\begin{array}{c}-0.028 * * \\
(0.006)\end{array}$ & $\begin{array}{c}-0.026 * * \\
(0.006)\end{array}$ \\
\hline \multicolumn{6}{|l|}{ Health Status } \\
\hline [Ref: Excellent or Very Good] & $\cdots$ & $\cdots$ & $\cdots$ & $\ldots$ & $\ldots$ \\
\hline Good & $\cdots$ & $\begin{array}{c}0.008 * * \\
(0.003)\end{array}$ & $\begin{array}{c}0.008 * * \\
(0.003)\end{array}$ & $\begin{array}{c}0.009 * * \\
(0.003)\end{array}$ & $\begin{array}{c}0.008 * * \\
(0.003)\end{array}$ \\
\hline Fair or Poor & $\cdots$ & $\begin{array}{c}0.016 * * \\
(0.004)\end{array}$ & $\begin{array}{c}0.016 * * \\
(0.004)\end{array}$ & $\begin{array}{c}0.019 * * \\
(0.004)\end{array}$ & $\begin{array}{c}0.016 * * \\
(0.004)\end{array}$ \\
\hline
\end{tabular}

(continued) 
Table 6 (continued).

(1)

Race

[Ref: White, Non-Hispanic]

Black, Non-Hispanic

Hispanic

Other, Non-Hispanic

State-Level Unemployment Rate

Log of Lifetime Earnings at Age 61

Change in Monthly Social Security Benefits from Delaying Claiming by One Month

Whether First Month of Eligibility

Age

[Reference: 62]

63

64

65 or older

$\mathrm{N}$

Pseudo R-squared

Mean of dependent variable
(2)

(3)

(4)

(5)

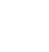

0.001

$(0.005)$

$(0.005)$

0.002

0.001

$(0.005)$

$-0.003$

$\begin{array}{lll}-0.002 & -0.002 & -0.002\end{array}$

$(0.007)$

$(0.007)$

$(0.007)$

$(0.007)$

$-0.014^{*}$

$-0.015^{*}$

$-0.016^{*}$

$-0.016^{*}$

(0.006)

(0.006)

$(0.006)$

$(0.006)$

$-0.0003$

$\begin{array}{lcc}0.0005 & 0.001 & -0.0003 \\ (0.001) & (0.001) & (0.001)\end{array}$

$\begin{array}{ll}\cdots & (0.001)\end{array}$

0.002

$-0.0001$

$(0.001)$

$(0.001)$

$0.001 * *$

$0.001^{* *}$

$(0.0002)$

$(0.0002)$

$-0.052 * *$

$-0.069^{* *}$

$(0.005)$

$(0.005)$

(1)

$\cdots$

$-0.075 * *$

(0.002)

$-0.069 * *$

(0.003)

$0.175 * *$

(0.054)

33,881

.0962

.0626

Source: Authors' computations from the 1984-2008 SIPP panels linked to administrative records, spanning the years 1983 to 2009 .

Note: Standard errors are in parentheses. The models are estimated on a person-month sample of women age 61 and 11 months or older with 40 years of covered earnings who have not yet claimed Social Security benefits.

$* * \mathrm{p}<.01 ; * .01 \leq \mathrm{p}<.05 ; \# .05 \leq \mathrm{p}<.10$ 
Table 7. Differential Effects by Educational Attainment on the Likelihood of Claiming Social Security Benefits, Women

\begin{tabular}{lll}
\hline & $\begin{array}{c}\text { Never } \\
\text { Attended } \\
\text { College }\end{array}$ & $\begin{array}{c}\text { Attended } \\
\text { College }\end{array}$ \\
\hline State Level Unemployment Rate & 0.001 & -0.001 \\
& $(0.001)$ & $(0.001)$
\end{tabular}

\section{Cohort}

$\begin{array}{lcc}1921-24 & 0.011 & 0.022 \\ & (0.009) & (0.014) \\ 1925-29 & -0.008 & -0.000 \\ & (0.007) & (0.008) \\ \text { [Reference: 1930-34] } & \ldots & \ldots \\ & & \\ 1935-39 & -0.003 & -0.007 \\ 1940-44 & (0.006) & (0.006) \\ & -0.012^{*} & -0.008 \# \\ 1945-47 & (0.006) & (0.005) \\ & -0.018^{*} & -0.007 \\ & (0.007) & (0.006) \\ & & \\ & 17,118 & 16,763 \\ & 0.0902 & 0.0619 \\ & 0.0746 & 0.0315\end{array}$

Source: Authors' computations from the 1984-2008 SIPP panels linked to administrative records, spanning the years 1983 to 2009 .

Note: Estimates show the marginal impact on the likelihood of claiming Social Security benefits. Standard errors are in parentheses. The models are estimated on a person-month sample of women age 61 and 11 months or older with 40 years of covered earnings who have not yet claimed Social Security benefits. In addition to the variables included in the table, the models also control for education, marital status, race, health status, age, natural log of lifetime earnings at age 61, the change in monthly Social Security benefits from delaying claiming by one month. and month of first eligibility for retirement benefits.

$* * \mathrm{p}<.01 ; * .01 \leq \mathrm{p}<.05 ; \# .05 \leq \mathrm{p}<.10$ 


\section{RECENT WORKING PAPERS FROM THE CENTER FOR RETIREMENT RESEARCH AT BOSTON COLLEGE}

Economic Consequences of the Great Recession: Evidence from the Panel Study of Income Dynamics

Barry Bosworth, February 2012

The Changing Causes and Consequences of Not Working Before Age 62

Barbara A. Butrica and Nadia Karamcheva, February 2012

The Impact of Temporary Assistance Programs on Disability Rolls and Re-Employment Stephan Lindner and Austin Nichols, January 2012

Understanding the Growth in Federal Disability Programs: Who Are the Marginal Beneficiaries, and How Much Do They Cost?

Adele Kirk, January 2012

What Explains State Variation in SSDI Application Rates?

Norma B. Coe, Kelly Haverstick, Alicia H. Munnell, Anthony Webb, December 2011

How Do Subjective Mortality Beliefs Affect the Value of Social Security and the Optimal Claiming Age?

Wei Sun and Anthony Webb, November 2011

How Does the Personal Income Tax Affect the Progressivity of OASI Benefits?

Norma B. Coe, Zhenya Karamcheva, Richard Kopcke, Alicia H. Munnell, November 2011

The Pension Protection Act of 2006 and Diversification of Employer Stock in Defined Contribution Plans

Gary V. Engelhardt, November 2011

Prescription Drug Insurance Coverage, Drug Utilization, and Cost-Related NonAdherence: Evidence from the Medicare Part D Expansion

Gary V. Engelhardt, November 2011

Social Security on Auto-Pilot: International Experience with Automatic Stabilizer Mechanisms

Barry Bosworth and R. Kent Weaver, November 2011

The Impact of Unemployment Insurance Extensions on Disability Insurance Application and Allowance Rates

Matthew S. Rutledge, October 2011

All working papers are available on the Center for Retirement Research website (http://crr.bc.edu) and can be requested by e-mail (crr@bc.edu) or phone (617-552-1762). 